\title{
Valuing Alpine ecosystems: the recharge.green project will help decision-makers to reconcile renewable energy production and biodiversity conservation in the Alps
}

\author{
Karin Svadlenak-Gomez, Marianne Badura, Florian Kraxner, Sabine Fuss, Daniele Vettorato \& Chris Walzer
}

Keywords: renewable energy, biodiversity conservation, ecosystem services, economic valuation, trade-offs, Alpine ecosystems

\section{Abstract}

Anthropogenic climate change threatens the global environment, including biodiversity, and with it continued human welfare. The European Union aims to increase its share of renewable energy (RE) to $20 \%$ by 2020 in an effort to reduce greenhause gas emissions while enhancing energy security and providing opportunities for economic development. The Alpine region is expected to contribute significantly to RE expansion. The trade-offs between potential gains and losses, especially for biodiversity, from new RE developments are rarely fully considered even though biodiversity loss has significant economic costs for society. The EU Alpine Space recharge.green project develops tools to evaluate the RE carrying capacity of the biodiversity-rich Alpine ecosystems. The tools will aid in the analysis of siting decisions and in weighing up costs and benefits to enable rational energy implementation decisions. The developed tools will be tested in five pilot regions in Austria, Germany, Italy, and Slovenia.

\section{Background}

There is now broad scientific consensus that climate change as a result of anthropogenic greenhouse gas (GHG) emissions is threatening the global environment, including biodiversity, and with it continued human welfare. By 2005 global atmospheric concentrations of the most important GHG carbon dioxide $\left(\mathrm{CO}_{2}\right)$ had soared from about $280 \mathrm{ppm}$ before the start of industrialization to $379 \mathrm{ppm}$ and the average annual rate of increase has been accelerating. Fossil fuel use contributes most, while land-use change produces about $30 \%$, of which $17.4 \%$ stem from deforestation and forest degradation (IPCC 2007).

The expansion of renewable energy (RE) is seen as one of the strategies to mitigate $\mathrm{CO}_{2}$ emissions. The European Union aims to increase its share of RE to $20 \%$ by 2020 in an effort to reduce GHG emissions while also enhancing energy security and providing opportunities for economic development (EC 2009). The RE Directive (2009/28/EC) recognizes the necessity to adapt the $20 \%$ target for individual Member States depending on each state's starting point and potential. The Alpine Convention too states in its Energy Protocol that the Alpine region will make a long-term contribution to meeting Europe's energy needs (EC 2005, p. 37) and expresses a commitment to increase the use of $\mathrm{RE}$ sources in the Alpine region.

In addition, the political decisions to phase out nuclear power in Switzerland and Germany (Dempsey \& Ewing 2011) and the Italian measure to delay national nuclear strategy development indefinitely (Pianigiani 2011) increase the pressure to exploit RE sources to provide the Alpine region with sufficient energy. The expansion of energy production and use affects ecosystem functions and nature conservation and should be supported by innovative decision support systems (DSS) and legal frameworks. An example of a gap in this field is Germany's new RE Law (EEG' (BMU 2012)), which offers different feed-

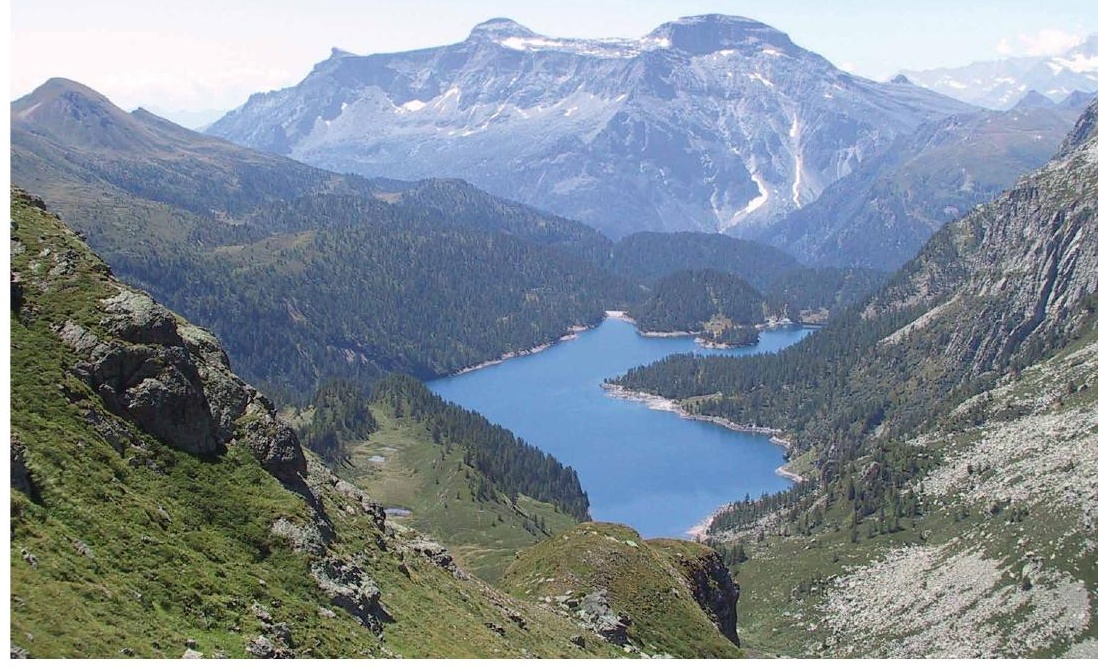

Figure 1 - Water reservoir for hydropower production (C) M. Revaz.

in tariffs depending on the RE source (quite low for small hydro- and much higher for solar power, e.g. Lang \& Mutschler 2012) but tends to disregard the ecological costs of production. Were one to consider the total economic value of energy produced by small hydropower plants, for example, its cost would often be exorbitant, given the ecological impacts and the plants' insignificant production capacity (BN 2012).

At the same time, over the past 50 years, biodiversity losses have been more dramatic than in all of previous human history and these changes continue and may be increasing in intensity (Hooper et al. 2012; MA 2005). The aims and provisions of global treaties and regional policy instruments, such as the Global Convention on Biological Diversity, the EU Habitats and Birds Directives, and, most recently, the EU 2020 Biodiversity Strategy, all reflect a shared concern about the decline of biodiversity. The Alpine Convention also acknowledges the need to limit the negative effects of power plants on the environment and the landscape (EC 2005, p. 38) and its Energy Protocol includes several clauses requiring the conservation of natural areas as habitats for wildlife. 
cation will be ideal for every type of RE system. Some of the variables that will affect suitability include the biodiversity ranking of a given location, its particular ecological and geographical situation, but also the socioeconomic needs. The project will draw on and further develop tools currently used by the project partners, such as IIASA's geographically explicit BeWhere model (e.g. Leduc et al. 2008) for optimal RE deployment and the open source GIS BIOMASFOR (Sacchelli et al. 2013) to assess the exploitability of forest biomass. The partners will expand the models to include hydro-, wind, and solar power. To analyse economic and ecological trade-offs, a marginal protection cost curve will be developed, which will be estimated using the model. This will take into account the protection status or biodiversity ranking of a location when calculating the per-unit costs of RE production. In areas with higher levels of biodiversity, energy production would be more costly than in those of relatively low biodiversity ranking. The use of such a tool will allow decisionmakers to obtain full information about costs and benefits and a good representation of the trade-offs involved. The tool will also integrate the map-based online survey tool Jecami, which was developed within the ETC Alpine Space project ECONNECT (http:// www.econnectproject.eu) to assess high biodiversity areas and ecological connectivity between them.

The project will test the developed tools in five pilot regions, with a focus on the areas' particularities: Alpi Marittime Nature Park (Italy), Bavaria (Germany), Triglav National Park (Slovenia), Veneto Region (Italy) and Vorarlberg (Austria). In general, activities within the pilot areas will test the instruments while involving local communities and integrating them into strategic environmental assessment processes for a choice of RE plans.

If the new tools can provide the basis within the pilot areas for balancing the demands for RE and for sourcing from those regions with the need to conserve their outstanding natural treasures, this would be an indicator of success for the recharge.green project.

The project began in October 2012 and will run until June 2015.

For more information: http:/ / www.recharge-green.eu

\section{References}

Ascough, J.C., H.D. Rector, D.L. Hoag, G.S. McMaster, B.C. Vandenberg, M.J. Shaffer, M.A. Weltz \& L.R. Ahjua 2002. Multicriteria spatial decision support systems for agriculture: Overview, applications, and future research directions. In: Integrated assessment and decision support proceedings of the 1st Biennial Meeting of the IEMSS: 175-180.

Atkinson, G., I. Bateman \& S. Mourato 2012. Recent advances in the valuation of ecosystem services and biodiversity. Oxford Review of Economic Policy 28 (1): 22-47.

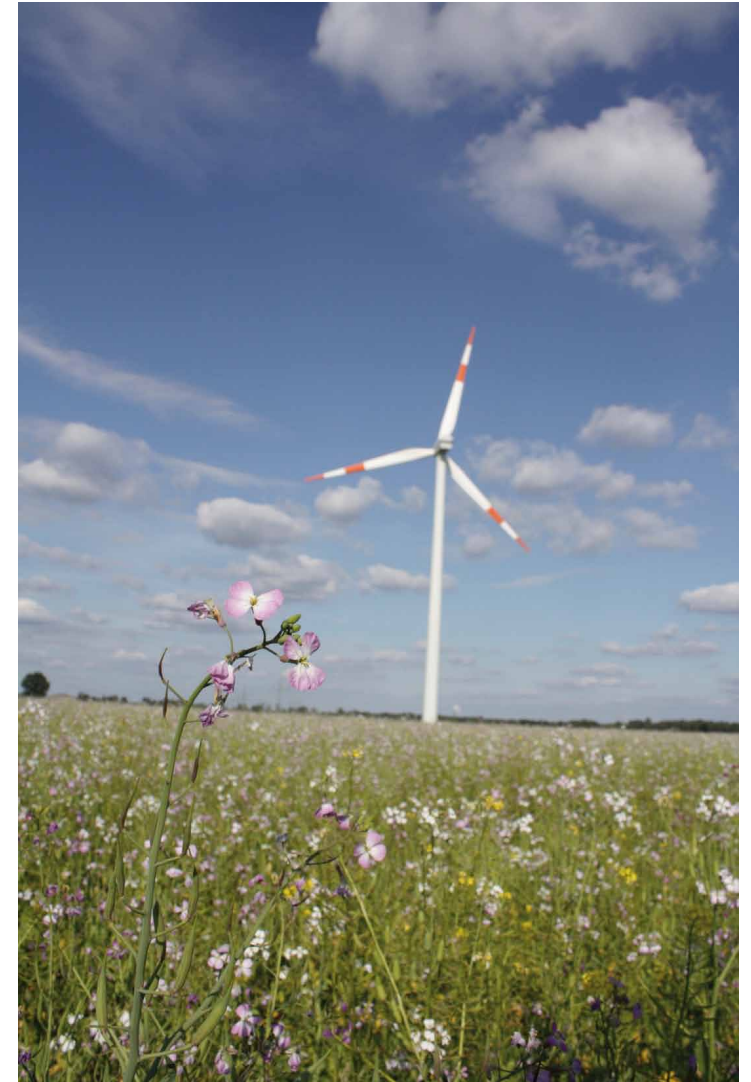

Figure 3 - Wind power plant. (C) Kenneth Brockmann pixelio.de

BMU 2012. Gesetz, für den Vorrang Erneuerbarer Energien (Erneuerbare-Energien-Gesetz, EEG 2012). Bundesministerium für Umwelt, Naturschutz und Reaktorsicherheit.

Bund Naturschutz in Bayern e.V. 2012. Einstimmig beschlossene Resolution der BNDelegiertenversammlung am 29. April 2012 in Günzburg. Schutz der Fließgewässer in Bayern: Kein weiterer Ausbau der Wasserkraft. Available at: http:// www.bund-naturschutz.de/uploads/media/DV_ Resolution-gegen-Wasserkraftausbau_DV-2012_1204-29.pdf (accessed: 11/03/13)

Braat, L.C. \& R. De Groot 2012. The ecosystem services agenda: bridging the worlds of natural science and economics, conservation and development, and public and private policy. Ecosystem Services 1 (1): 4-15.

Daily, G.C., S. Polasky, J. Goldstein, P.M. Kareiva, H.A. Mooney, L. Pejchar, T.H. Ricketts, J. Salzman \& R. Shallenberger 2009. Ecosystem services in decision making: time to deliver doi:10.1890/080025. Frontiers in Ecology and the Environment 7 (1): 21-28.

Dempsey, J. \& J. Ewing 2011. Germany to Close All Nuclear Plants by 2022. NYTimes.com. Available at: http://www.nytimes.com/2011/05/31/world/ europe/31 germany.html?_r=1\& (accessed: 09/01/13)

EC 2009. Directive 2009/28/EC of the European Parliament and of the Council of 23 April 2009 on the promotion of the use of energy from renewable sources and amending and subsequently repealing Directives 2001/77/EC and 2003/30/EC Text with 
EEA relevance. Official Journal of the European Union L 140: $16-62$.

EC 2005. Protocol on the implementation of the Alpine Convention of 1991 in the field of energy. Official Journal of the European Union L 337: 36-41.

EP 2012. European Parliament resolution of 20 April 2012 on our life insurance, our natural capital: an EU biodiversity strategy to 2020 (2011/2307(INI)) Available at: http://ec.europa.eu/environment/ nature/biodiversity/comm2006/pdf/EP_resolution_ april2012.pdf (accessed: 11/03/13)

Hooper, D.U., E.C. Adair, B.J. Cardinale, J.E.K. Byrnes, B.A. Hungate, K.L. Matulich, A. Gonzalez, J.E. Duffy, L. Gamfeldt \& M.I. O'Connor 2012. A global synthesis reveals biodiversity loss as a major driver of ecosystem change. Nature 486: 105-108.

IPCC 2007. Climate Change 2007: Synthesis Report. Contribution of Working Groups I, II and III to the Fourth Assessment Report of the Intergovernmental Panel on Climate Change. Pachauri, R.K. \& A. Reisinger (eds.). Geneva, Switzerland: Intergovernmental Panel on Climate Change (IPCC).

Lang, M. \& U. Mutschler 2012. German Feedin Tariffs 2012. German Energy Blog. Available at: http:/ / www.germanenergyblog.de/?page_id $=8617$ (accessed: 25/12/12)

Lassen, B. \& S. Savoia 2005. European Alpine Programme. Ecoregion Conservation Plan for the Alps. Bellinzona, Switzerland: WWF.

Leduc, S., D. Schwab, E. Dotzauer, E. Schmid \& M. Obersteiner 2008. Optimal location of wood gasification plants for methanol production with heat recovery. International Journal of Energy Research 32 (12): 1080-1091.

MA 2005. Ecosystems and Human Well-being: Biodiversity Synthesis. Millennium Ecosystem Assessment. World Resources Institute (WRI) (ed.). Washington, DC: World Resources Institute.

Martin-Lopez, B., C. Montes \& J. Benayas 2008. Economic Valuation of Biodiversity Conservation: the Meaning of Numbers. Conservation Biology 22 (3): 624-635.

Midgley, G.F. 2012. Biodiversity and Ecosystem Function. Science 335 (6065): 174-175.

Pianigiani, G. 2011. Italy: Nuclear Plants On Hold. NYTimes.com. Available at: http://www.nytimes. com/2011/04/20/world/europe/20briefs-italy.html (accessed 09/01/13)

Sacchelli, S., I. De Meo \& A. Paletto 2013. Bioenergy production and forest multifunctionality: A trade-off analysis using multiscale GIS model in a case study in Italy. Applied Energy 104: 10-20.

Sukhdev, P., H. Wittmer, C. Schröter-Schlaack, C. Nesshöver, J. Bishop, P. ten Brink, H. Gundimeda, P. Kumar \& B. Simmons 2010. Mainstreaming the Economics of Nature: A synthesis of the approach, conclusions and recommendations of TEEB.

\section{Authors}

\section{Karin Svadlenak-Gomez}

holds an MSc in Biodiversity Conservation and Management from the University of London. She has been with the Research Institute of Wildlife Ecology since 2011. She is experienced in sustainable development and conservation issues in an international context. Email: karin.svadlenak-gomez@fiwi.at

\section{Marianne Badura ${ }^{2}$}

graduated in landscape planning and GIS at the University of Applied Sciences Weihenstephan and the University of Salzburg. In 1998 she set up her own company blue! and has been involved in it as managing partner and as expert in landscape ecology and European environmental topics. Email: m.badura@ the-blue.net

\section{Florian Kraxner ${ }^{3}$}

is Deputy Leader of IIASA's ESM Program. He graduated in forestry with specialization in mountain risk engineering and watershed management from the University of Natural Resources and Life Sciences, Vienna. His current research interests are: land-use change, sustainable forestry and bioenergy. Email: kraxner@iiasa.ac.at

\section{Sabine Fuss ${ }^{3}$}

completed her $\mathrm{PhD}$ in economics at Maastricht University and UNU-MERIT. Since 2007 she has been working at the International IIASA's ESM Program. Her research interests include: decision making under uncertainty, energy planning, natural resource management and climate change. Email: fuss@iiasa.ac.at

\section{Daniele Vettorato ${ }^{4}$}

coordinates the research group in Energy Strategies and Planning at the EURAC Institute for Renewable Energy. He also collaborates with Trento University and is a member of the International Society of Cities and Regional Planners. He has a PhD in Environmental Engineering - Sustainable Planning (Energy). Email: daniele.vettorato@eurac.edu

\section{Chris Walzer}

is a veterinarian by training. He holds the Chair for Conservation Medicine and is Co-director of the Research Institute of Wildlife Ecology. His internationally recognized wildlife expertise has been gained from combined years of work and research in Europe, Asia and Africa. Email: chris.walzer@fiwi.at

${ }^{1}$ Research Institute of Wildlife Ecology, Vetmeduni Vienna

${ }^{2}$ blue! advancing european projects

${ }^{3}$ International Institute for Applied Systems Analysis

${ }^{4}$ EURAC, Bolzano, Institute for Renewable Energy 